\title{
„Fény és árnyék" nemzetközi kitekintésben: A turizmus két oldala - nemcsak a turista lehet áldozat...
}

\author{
Szerzők: Ernszt Ildikó
}

A vágyak iparágában, azaz a turizmusban mindenki megpróbálja a saját álmait valóra váltani. Ez azonban nemcsak idegen kultúrák, emberek, a földi tájak szépségének a megtapasztalását jelenti sokak számára, hanem mások kihasználását, mások szenvedéséből való gazdagodást, vagy egyszerúen a helyi közösségek érdekeinek a semmibe vételét. A cikkben annak a vizsgálatára kerül sor, hogy melyek azok a negatív jelenségek, amelyek a turistákkal együtt megjelennek a desztinációkban, és a helyi lakosság biztonságát veszélyeztetik. Ugyanis az iparág érthetô okokból rendkivül ",turista-, azaz vendégcentrikus", és hajlamos teljes mértékben elfelejtkezni a másik oldalról: a vendéglátókról. Holott a turisták sok esetben rossz vendég módjára "lerohanják" a desztinációkat, törnek-zúznak, randalíroznak, és nemcsak a pénztárcájukat hozzák $a$ "böröndjeikben", hanem a sötét vágyaikat is. Olyanok pedig mindig voltak, és lesznek is, akik ezeket az ördögi szenvedélyeket - természetesen jó pénzért - kielégítik. Az úti célok lakosságának leginkább veszélyeztetett csoportjai közé a gyermekek, nôk, idôsek tartoznak, akik a sérülékenységüknek köszönhetôen még könnyebben áldozattá válhatnak. A cikk a teljesség igénye nélkül emlit meg néhány, a desztinációkban éló lakosság biztonságát veszélyeztetô jelenséget, büncselekményt: a szexturizmust, ezzel kapcsolatban külön kiemelve a gyermekprostitúciót, illetve a gyermekmunka és gyermekkereskedelem büntettét. Végezetül javaslatok tételére is sor kerül a vendéglátók védelme érdekében, hiszen ennek elmulasztása esetén nagy árat kell fizetnünk.

Kulcsszavak: deviancia, szexturizmus, gyermekmunka, emberkereskedelem.

\section{A vágyak iparága mindenkié - a búnözóké is...}

A turizmus a „vágyak, álmok iparága”, ahol minden valóra válhat, legalábbis pár napra. Az ember kiszakad a mindennapok mókuskerekéból, egy kis ideig „úr" lehet, és lesik minden kívánságát, vagy egy kicsit szabadnak érezheti magát, amikor többet engedhet meg magának. Azzal együtt, hogy tömegek számára váltak elérhetővé a nyaralások, wellness hétvégék és városlátogatások, elbúcsúzhattunk attól az illúziónktól, hogy mindig biztonságban érezzük magunkat a nyaralás alatt. A biztonság kiemelkedően fontos tényező az utazási döntések meghozatala során.

Lengyel szerint a „turisztikai termék a turista motivációjának megfelelő attrakcióra (vonzerőre) épülő komplex szolgáltatáshalmaz", amiben a közlekedés, szállás, étkezés mellett megjelenik a biztonság is (LENGYEL 1997:10). A biztonság rendkívül tág fogalomként értelmezhetô a turizmus

\footnotetext{
1 egyetemi docens, Pannon Egyetem Nagykanizsai Kampusz, ernszt.ildiko@uni-pen.hu
}

vonatkozásában: érthetô alatta a jogellenes cselekményekkel, a búnözéssel szembeni biztonság, de a technikai - múszaki értelemben vett biztonság is: az épített környezet, a fogyasztás, akár az eligazodás biztonsága.

A tömegturizmus és a deviáns magatartások általában kéz a kézben járnak, hiszen ahol tömegek jelennek meg, ott szinte törvényszerúen mindig felüti a fejét a deviancia is. BIAGI és kutatótársai Olaszországban vizsgálták azt, hogy a turizmus milyen hatással van a búnözésre. Megállapították, hogy rövid távon a turistaérkezések mértékének 1\%-os növekedése 0,018\%-os növekedést idéz elő a búnözések számában, míg hosszú távon ez a hatás 0,11\% (BIAGI et al. 2012).

A kutatók több okot azonosítottak, amelyek miatt érzékelhetô ez a negatív hatás. Az embereknek mindig is voltak, vannak, és lesznek deviáns, sötét vágyai. Sokan specializálódnak ezeknek a vágyaknak a valóra váltására, hiszen abból profitra lehet szert tenni. Wolf (1997) így fogalmaz erről: „Kérdezz meg egy helyit egy harmadik világbeli desztinációban arról, hogy mit jelent számukra a turizmus: el fogják mondani, hogy ez puszta üzlet: kiárusítják a környezetüket, a kultúrájukat és a vendégeknek ajánlott szolgál- 
tatásaikat." (WOLF 1993, idézi: DAHLES - BRAS 1999:286).

Prostitúcióra, gyermekprostitúcióra, kényszermunkára kényszerítés, emberkereskedelem, csalás, zsebtolvajlás, lopás, terrorizmus - csak néhány példa a búnözók búnlajstromáról. De a feketegazdaság felvirágzása is tipikus a turizmus iparágban, ami szorosan kapcsolódik a szervezett búnözéshez, hiszen a hotelek, vendéglátó egységek múködtetése során könnyedén tisztára lehet mosni a búncselekmények elkövetése révén szerzett „piszkos pénzt" (BADARIAH et al. 2016). Egyes kutatók szerint Európában a feketegazdaság 20-25\%-a kapcsolatba hozható a turizmussal (SCHNEIDER et al. 2013), és megállapítják, hogy a feketegazdaság enyhítése, felszámolása hozzájárulhatna az ágazat növekedéséhez (BADARIAH et al. 2016, PÉTER et al. 2017).

Emellett a turizmus sajátosságaiból fakadóan vonzza a búnelkövetőket: a turisták könnyú prédának bizonyulnak, hiszen nem ismerik a nyelvet, a környezetet, a szokásokat, és sok esetben óvatlanabbak is a nyaralás ideje alatt. Nem szívesen tesznek feljelentést az ezzel járó hercehurca elkerülése érdekében, és sokszor hordoznak magukkal nagyobb pénzösszeget vagy drágább értéktárgyakat.

Azonban nemcsak a turisták válhatnak áldozattá, hanem maga a helyi lakosság is. A sok esetben tömegesen érkező turisták megjelenésével fellángolhat az igény a prostitúció, a drogok iránt, felütheti a fejét az emberkereskedelem. A nagy turisztikai szolgáltató láncolatok sokszor kizsákmányolják a helyi lakosság munkaerejét, éhbérért foglalkoztatva a helyieket, adott esetben gyermekeket is. A tömegturizmus jelentôs mértékú környezetszennyezést eredményezhet, ami ronthatja a helyi lakosok életminőségét (ERNSZT 2016b).

Arra vonatkozóan, hogy milyen mértékben esnek a búnözés áldozatául helyiek, és milyen arányban turisták, nincsenek pontos, megbízható búnügyi adatok, statisztikák. A tömegturizmus folyamatai a "kitapasztalható biztonság” érzete nélkül nehezen értelmezhetőek (ZSARNOCZKY 2017).

Így tehát amellett, hogy nagy bevételt jelent az országoknak a turizmus, van egy másik oldala is: a turisták léte növelheti a búnözés mértékét, ami „nemcsak egy olyan költség, amit a helyi lakosságnak kell kifizetnie, hanem a késóbbiekben el is riaszthatja a potenciális turistákat" (BIAGI et al. 2012:1). De a búnözés léte a turisztikai vállalkozásokra is lesújtó következményekkel jár: negatív hatással van a hotelek múködési teljesítményére (HUA - YANG 2017).

\section{Egyes deviáns magatartások megjelenése a desztinációkban}

\subsection{SZEXTURIZMUS}

Egyes desztinációk a szexturizmus színhelyeiként váltak ismertté. Erre a kétes hírnévre tett szert Thaiföld, Jamaika, Amszterdam, és Las Vegas. Ugyanakkor már azt is felvetették, hogy le kell számolnunk a régi, egyszerú képpel, miszerint gazdag nyugati országokból származó férfiak zsákmányolják ki a nóket, lányokat, ezáltal rabszolgaságba taszítva óket.

Noha kétségkíviul létezik a jelenség, ma már korántsem ilyen egyszerú a képlet. Már nagyon régóta a nők is megjelennek a szexualitást máshol keresők között, és sokszor kalandra, románcra is vágynak utazásuk során a dél-amerikai, afrikai fiúk karjaiban. Érdekes, hogy még arról is vita zajlott a szakirodalomban, hogy a nók szexualitást kereső utazásait romantikus turizmus vagy szimplán szexturizmus néven illessék, hiszen nehéz volt elfogadni, hogy a nók ezirányú turizmusa semmiben sem különbözik a férfiakétól, és ők is lehetnek a másik nemhez hasonló szexuális ragadozók (BAUER 2014, SPENCER BEAN 2017).

Egy Jamaikában végzett kutatás pedig arra az eredményre jutott, hogy még a helyiek is másként ítélik meg a szexuális kalandokat keresô nóket, mint a férfiakat: míg a férfiakról úgy gondolják, hogy pusztán szexuális élményekre vágynak, addig a nők romantikára. Ezt megcáfolják azonban a nőnemú turisták válaszai, amikból kiderül, hogy ugyanolyan céljaik vannak, mint férfi társaiknak. Ahogy egy interjúalany megfogalmazta: „A mindennapi életben bezárod a démonjaidat a szekrénybe, és lecsendesíted óket. De amikor nyaralni mész, kinyitod a gardróbot, és azt mondod nekik: Kifelé! Szórakozzatok!" (BERDYCHEVSKY et al. 2013:76). Sót, ez a furcsa kettősség az ilyen igényeket kiszolgáló személyeknek a saját magukról alkotott képében is megjelenik: míg a szexuális szolgáltatásokat nyújtó nők prostituáltnak tekintették magukat, a hasonló tevékenységet úző férfiak kísérőként, beachboyként néztek önmagukra (SPENCER - BEAN 2017).

Latin-Amerikától Afrikán át Ázsiáig számos helyen van jelen a női szexturizmus: így Jamaikában (SPENCER - BEAN 2017), Ecuadorban, Kubában, Barbadoson, a Karibtérségben (WEICHSELBAUER 2012), Gambiában, Kenyában (OMONDI - RYAN 2017), Tanzániában, Indonéziában (DAHLES - BRAS 1999), vagy akár Buenos Airesben, az úgynevezett tangó turizmussal fémjelezve (BAUER 2014). 
Emellett az is vizsgálatra érdemes, hogy vajon az ázsiai férfiak, akik köztudottan vonzónak tartják a fehér bőrú nőket, és a média azt sugallja nekik, hogy a nyugati nők könnyúvérúek, milyen keresletet támasztanak az efféle szolgáltatások iránt.

Odáig is elmegy BANDYOPADHYAY (2013), hogy egyenesen paradigmaváltásról beszél a szexturizmusban (BAUER 2014). Említésre méltó az a futurisztikusnak ható elképzelés is, hogy humanoid robotok biztosítják a szolgáltatásokat a szexturizmus hagyományos helyszínein, ezáltal az ember-és gyermekkereskedelem, a nők és gyermekek kizsákmányolása csökkenne a feltételezés szerint (YEOMAN - MARS 2012).

\subsection{GYERMEKPROSTITÚCIÓ}

Sok esetben gyermekek válnak szexuális vágyak kielégítésének áldozatává. A gyermekek testét is áruba bocsátják, mint valami egzotikus árut, illetve szolgáltatást, amit ugyanúgy meg lehet vásárolni, mint bármilyen egyéb árucikket vagy szuvenírt. A nyomor és a hiszékenység vámszedőinek semmi sem számít, gyermekeket taszítanak a prostitúció poklába.

A turizmusban a gyermekek szexuális kizsákmányolásának pontos definíciója mind a mai napig hiányzik, ami jelentôs mértékben megnehezíti az ellene történő fellépést. Egy nemzetközi, a gyermekek mindennemú szexuális kizsákmányolása ellen küzdő civil szervezet, az ECPAT (End Child Prostitution and Trafficking) javaslata szerint "minden, az utazás, a turizmus keretein belül történő, a gyermekek szexuális kizsákmányolását célzó cselekményt" ide kell sorolni (HAWKE - RAPHAEL 2016:106).

Azt hinnénk, hogy a jelenség eltúnőben van, azonban ezzel az illúziónkkal is le kell számolnunk, hiszen a turizmus robbanásszerú növekedésével párhuzamosan a gyermekprostitúció is egyre virágzóbb, és egyre szélesebb földrajzi térségekben megjelenő iparág. Már nem korlátozódik az olyan desztinációkra, ahol „hagyománya van" ennek a deliktumnak, mint például Délkelet-Ázsia és Latin-Amerika. Vannak „feltörekvőben levő" új úti célok, amelyek felkerültek erre a kétes hírú térképre, ilyen például Európa és Észak-Amerika.

Sajnos Magyarország is érintett a témában. 2018 február végén arról tudósítottak a hírportálok, hogy 12 zalai személy ellen vádat emeltek kerítés, valamint gyermekprostitúció kihasználásának búntette miatt. A vádlottak 2011 és 2016 között kiskorú lányokat is közvetítettek számos külföldi országba (Németországba, Katarba, Malajziába), ahol online árusították szexuális szolgáltatásaikat (MAGYARORSZÁG ÜGYÉSZSÉGE 2018).
A szolgáltatásokat igénybe vevők köre is kiszélesedett, és csak ámítanánk magunkat, ha azt hinnénk, hogy tipikusan külföldi elkövetőkkel kell szembenézni. Belföldiek is meglehetősen nagy számban jelentek meg az elkövetók között, Ázsiában ugyanúgy, mint Európában vagy Észak-Amerikában. Az a kép él bennünk, hogy az elkövetők többsége biztosan pedofil, azonban ez sem igaz. Egy 2003-ban készített olasz kutatás szerint az olasz elkövetóknek csak 3\%-a volt pedofil, a többi teljesen átlagosnak tekinthetó férfi és nó (O'BRIAIN et al. 2008, NEWMAN 2011). A tettesek legtöbbje azért követi el a cselekményt, mert éppen lehetősége adódik rá, nem feltétlenül ezért utazott el, az „alkalom szüli a szexuális kizsákmányolót" elv érvényesül.

Jellegzetes, hogy a szexuális ragadozók mindig felmentik magukat az alábbiakhoz hasonlatos kifogásokkal: „elég idős ahhoz, hogy tudja, mit csinál", „semmi rosszat nem tettem, hiszen kifizettem, amit kért" (HAWKE - RAPHAEL 2016:100).

$\mathrm{Az}$ áldozatok tipikusan a társadalom szegényebb rétegeiből jönnek. Iskolázottság, iskolai oktatás híján, a nyomor miatt előfordul, hogy a saját családjuk adja óket erre a sorsra, de a legtöbbjük az utcán éló, diszfunkcionális családból származó, sokszor családi erőszak terrorja alatt tartott gyermek. Gyakori, hogy az utánpótlást az árvaházak biztosítják.

Azonban még egy aggasztó jelenség ütötte fel a fejét, amire eddig nem volt ilyen mértékben példa: az anyagi javak megszerzésének vágyától elkábítva a középosztályból származó gyermekek is megjelentek a gyermekprostitúció áldozatai között. Öket azok az anyagi javak, illetve az azokkal elérhetó státusz, elismerés vakítják el, amiket a könnyúnek látszó pénzkeresettel meg lehet szerezni. A cselekedeteik rendkívül súlyos következményeit fel sem tudják mérni. Az egzotikus kinézetú, a többiektől kissé különböző gyermekek még nagyobb veszélynek vannak kitéve, hiszen nagyobb irántuk a kereslet (HAWKE - RAPHAEL 2016).

A gyermekprostitúcióval szembeni küzdelmet nagyon sok tényezó nehezíti. Mivel jellege miatt a búncselekmény „rejtőzködő”, nagyon nehéz pontos adatokat megállapítani a mértékéról, az elérhető adatok pedig, ha egyáltalán léteznek, mindig csak a jéghegy csúcsát jelentik csupán (1. táblázat).

Mivel nincs egyértelmúen körülhatárolható, tipikus elkövetói csoport, sem pedig áldozati kör, nehéz az elkövetôkkel szembeni fellépés. Az internet pedig igencsak megkönnyítette az elkövetők dolgát, hisz online könnyen kapcsolatba kerülhetnek potenciális áldozataikkal, annak adják ki magukat, akinek csak akarják, sôt egyéb információkat is könnyen szerezhetnek. A búncselekménnyel 
szembeni fellépés két oldalról közelíthető meg egyrészt a „kínálat” csökkentésének oldaláról (úgy, hogy a gyermekek eltûnnek az utcákról), másrészt a kereslet oldaláról (amikor a potenciális elkövetôket rettentik el a búnelkövetéstől) (CHEMIN MBIEKOP 2015).

\section{A gyermekek turizmusban történô szexuális kizsákmányolása elleni fellépést nehezítő tényezók, kihívások}

\begin{tabular}{|c|c|c|}
\hline $\begin{array}{l}\text { Társadalmi } \\
\text { problémák }\end{array}$ & $\begin{array}{c}\text { Végrehajtás } \\
\text { problémái }\end{array}$ & Egyéb \\
\hline $\begin{array}{l}\text { - a probléma } \\
\text { gyökere nehezen } \\
\text { kezelhetó } \\
\text { - a búncselek- } \\
\text { mény társadalmi } \\
\text { elfogadottsága } \\
\text { - társadalmi } \\
\text { szokások } \\
\text { - pénzéhség } \\
\text { - tabu } \\
\text { - gyermekek alac- } \\
\text { sony társadalmi } \\
\text { státusza bizon- } \\
\text { yos helyeken }\end{array}$ & $\begin{array}{l}\text { - normák hiánya } \\
\text { - megbízható } \\
\text { adatok hiánya } \\
\text { - magas látencia } \\
\text { - végrehajtást } \\
\text { segitó források } \\
\text { hiánya } \\
\text { - korrupció } \\
\text { - hatóságokkal } \\
\text { szembeni bizal- } \\
\text { matlanság }\end{array}$ & $\begin{array}{l}\text { - az online világ } \\
\text { könnyebbé tette } \\
\text { a büncselekmény } \\
\text { elkövetését } \\
\text { - új desztinációk } \\
\text { gyors meg- } \\
\text { jelenése } \\
\text { - bünözôk gyors } \\
\text { alkalmazkodása } \\
\text { a megváltozott } \\
\text { körülményekhez } \\
\text { - az elkövetôi pro- } \\
\text { fil változása } \\
\text { - új elkövetési } \\
\text { helyszínek } \\
\text { - egyre fiatalabb } \\
\text { áldozatok }\end{array}$ \\
\hline
\end{tabular}

Forrás: ERNSZT (2018), UN GA (2008), HAWKE - RAPHAEL (2016) és a 'Report of the 30th meeting of the World Tourism Network on Child Protection' (2015) alapján

Számos nemzetközi jogi, illetve nemzeti norma lép fel a búntettekkel szemben, azonban nagyon nehéz foganatosítani őket egy ilyen rejtett jellegú búncselekménynél, különösen akkor, amikor többek között a gyökereit - a szegénységet, nyomort, iskolázatlanságot - kellene felszámolni a valódi változáshoz. Emellett több országban a korrupció, a hatóságok elnéző magatartása, a desztináció kultúrája, a gyermekekkel szembeni erőszak bizonyos mértékú elfogadottsága is nehezíti a harcot (HAWKE - RAPHAEL 2016).

A fellépést nemcsak a jogi normák segítik, számos nemzetközi szervezet, sőt vállalkozásokat tömörítő szervezet is aktív a területen. A nemzetközi szervezetek közül ki kell emelni az ENSZ egyik szakosított szervezetét, a Turisztikai Világszervezetet (a továbbiakban: UNWTO), amelynek külön munkacsoportja szolgál a gyermekek szexuális kizsákmányolása elleni harc platformjaként a turizmusban.

A vállalkozásoknak is fontos szerepe van az ilyen bû́ncselekmények visszaszorításában. A gyermekeknek a turizmusban történő kizsákmányolása ellen már számos vállalkozás szót emel a CSR (társadalmi felelősségvállalás) politikájában. A „The Code” egy, a turisztikai ipar által útjára indított kezdeményezés, ami platformként funkcionál a gyermekekkel szembeni szexuális kizsákmányolás minden formájának megszüntetése érdekében. A szervezet meggyőződése, hogy a felelősségteljes turisztikai vállalkozások a kulcsszereplők ebben a harcban. Amikor egy vállalkozás csatlakozik a „The Code”-hoz, 6 lépés megtételét vállalja (1. ábra).

1. ábra

\section{A „The Code" által elóírt követelmények a csatlakozó vállalkozások számára}

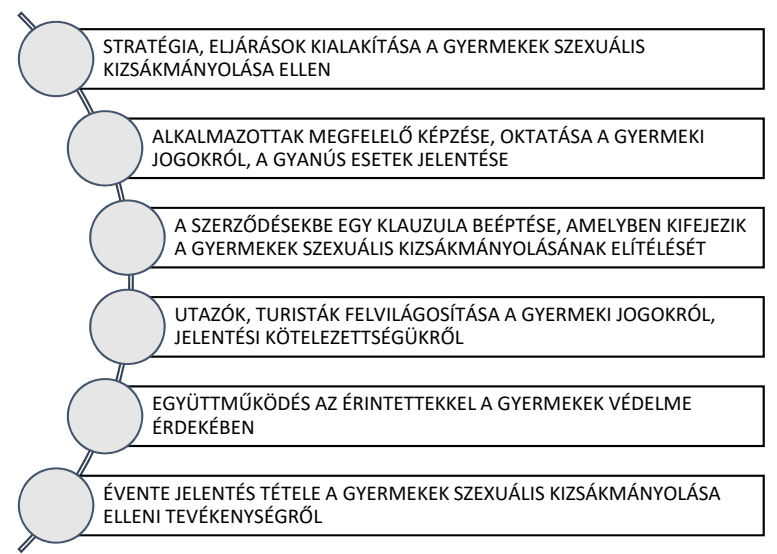

Forrás: saját szerkesztés UNWTO (2014) alapján

Online felület és interaktív online oktatási anyag is segíti a csatlakozó vállalkozásokat. Ahogy azt a szervezet is hangsúlyozza, számos előnye lehet a csatlakozásnak. Többek között segít egy pozitív imázs kialakításában, és egy network-öt hoz létre a hasonló értékek mentén múködő vállalkozások között (THE CODE).

\subsection{EMBERKERESKEDELEM, GYERMEKMUNKA}

A nók, gyermekek kereskedelme különösen jelentős, hiszen a szexuális kizsákmányoláshoz így biztosítják az áldozatokat, ami hatalmas üzlet. Természetesen ezek a bû́ncselekmények szorosan öszszefonódnak a szervezett búnözéssel (INTERPOL 2018). A gyermekek nemcsak szexuális szolgáltatások nyújtása, hanem egyéb búncselekmények elkövetése céljából is a modern kori rabszolgapiacra kerülnek: zsebtolvajnak, szervezett búnözői csoportok tagjainak, emellett nagyon könnyen pótolhatóknak, helyettesíthetőknek tekintik őket (ILO 2009). 
A turizmus szektornak - különös tekintettel a hotel szektorra - több funkciója is van ebben a folyamatban, hiszen egyrészt lehetőséget biztosít az ember- és gyermekkereskedelemre, másrészt a búncselekmény áldozatául esett személyek munkát kapnak az iparágban, ugyanakkor nagyon nagy szerepe lehet a megelózésben is (PARASKEVAS - BROOKES 2018).

A gyermekek szexuális kizsákmányolása, a gyermekkereskedelem cselekmények kéz a kézben járnak a gyermekmunkával, ami ebben az esetben az egyik legkegyetlenebb formában jelenik meg. Emellett a turizmus világában, ami nagyon munkaerôigényes, sok egyéb pozícióban is lehet gyermekmunkásokkal találkozni világszerte, fóként a fejlődő országokban. A hotelalkalmazottak, portások, takarítók, konyhai kisegító személyzet, virág-, újság- és szuvenírárusok között egyaránt előfordulhatnak. A hivatalos statisztikák adatai alapján Indiában 13 millió gyermeket foglalkoztat a turisztikai ipar, míg nem hivatalosan 60-100 millió közötti mértékúnek becsülik a gyermekmunkások számát (SHARMA et al. 2012).

2. táblázat

\section{A Petrában alkalmazott modell a gyermekmunka felszámolására}

\begin{tabular}{|l|l|}
\hline \multicolumn{1}{|c|}{ Érintettek } & \multicolumn{1}{c|}{ Szükséges lépések } \\
\hline $\begin{array}{l}\text { gyermekek, } \\
\text { az egész közösség }\end{array}$ & oktatás \\
\hline $\begin{array}{l}\text { a turisztikai szektor } \\
\text { valamennyi szereplóje }\end{array}$ & $\begin{array}{l}\text { a problémára történó } \\
\text { figyelemfelhívás és az azzal } \\
\text { kapcsolatos tanácsadás }\end{array}$ \\
\hline $\begin{array}{l}\text { jogalkotást, } \\
\text { végrehajtást, } \\
\text { igazságszolgáltatást } \\
\text { végzó szervek }\end{array}$ & $\begin{array}{l}\text { a megfelelő jogi szabályozás } \\
\text { mellett annak hatékony } \\
\text { végrehajtása }\end{array}$ \\
\hline $\begin{array}{l}\text { közösség tagjai, } \\
\text { családok }\end{array}$ & $\begin{array}{l}\text { garantálása annak, hogy egyéb } \\
\text { forrásokból képesek legyenek } \\
\text { az érintett családok, gyermekek } \\
\text { fedezni a létfenntartásuk } \\
\text { költségeit }\end{array}$ \\
\hline $\begin{array}{l}\text { szociális, } \\
\text { gyermekvédelemért } \\
\text { felelös szervek }\end{array}$ & $\begin{array}{l}\text { veszélyeztetett gyermekek } \\
\text { beazonosítása } \\
\text { megfelelő társadalmi védóháló } \\
\text { kiépitése }\end{array}$ \\
\hline
\end{tabular}

Forrás: saját szerkesztés PETRA DEVELOPMENT AND TOURISM REGION AUTHORITY et al. (2014) és UNICEF (2011) alapján

A legtöbb esetben a gyermekmunkások is a legszegényebb, a hangjukat legkevésbé hallatni tudó családokból kerülnek ki. Sokszor természeti katasztrófák - cunami, szárazság, árvizek - által sújtott térségekből, fegyveres konfliktusokkal terhelt, vagy egyéb, politikai szempontból instabil térsé- gekből származnak. Szívesen alkalmazzák őket, hiszen könnyebb velük (el)bánni, nem panaszkodnak, éhbérért is dolgoznak. Azonban mind a társadalom, mind a gyermek szempontjából nagyon súlyos következménnyel jár a jelenség (SHARMA et al. 2012).

A jordániai Petra turisztikai iparában megjelenó gyermekmunka jelenségének a felszámolására már egy akciótervet is kidolgozott együtt a Petra Regionális Turisztikai Fejlesztési Szervezet, a Nemzetközi Munkaügyi Szervezet (ILO), az ENSZ Nemzetközi Gyermek Gyorssegélyalap (UNICEF) és a jordán Munkaügyi Minisztérium (2. táblázat). Az elkészített program kitúnő példa arra, hogy egy ilyen összetett jelenséget kizárólag holisztikus megközelítéssel lehet kezelni. Mind a megelôzés, mind a terápia csak holisztikus megközelítéssel lehetséges.

\section{Néhány következtetés és javaslat}

\section{1. ÁLTALÁNOS MEGJEGYZÉSEK}

A turizmusnak mindig is voltak negatív következményei, azonban nagyon aggasztó, hogy ezek a turizmus robbanásszerú bóvülésével párhuzamosan egyre inkább terjednek. Nem szabad elfelejtkezni arról, hogy a biztonsághoz nemcsak a turistáknak lenne joga, hanem a desztinációk lakosságának is.

A védtelen csoportok - nők, gyermekek - kizsákmányolása, a turizmus kapcsán tömegesen megjelenó búncselekmények fertőző betegségként betegítenek meg új térségeket és országokat. Illúzió lenne azt hinni, hogy teljes mértékben fel lehet számolni a turizmus negatív következményeit, de apró lépéseket lehet tenni.

Morális elvek tényleges beépítésére lenne szükség a turizmus iparágának múködtetésébe, a felelós turizmus sokszor már elkoptatott, kissé elnyútt fogalmát meg is kellene valósítani. Persze ez csak úgy lehetséges, ha az azt múködtetó érintettek figyelembe veszik az erkölcsi elveket, hisz az elvek puszta deklarálása nem elég.

Tudatosítani kell a turisztikai iparág valamenynyi szereplöjében, hogy a turizmus negatív következményeinek megelôzése, a biztonságos desztinációk garantálása a turizmus érdeke is, hiszen a biztonság fontos kitétel, alapkövetelmény az utazási döntések meghozatala során. A kétes hírnévre szert tevő desztinációk egy idő után elveszíthetik vonzerejüket, autentikusságukat, és a minôségi turizmust keresők elkerülhetik őket, ellenben olyan csoportokat csábítanak magukhoz, akik még nagyobb keresletet jelentenek a búncselekményekre. Ehhez azonban arra van szükség, hogy a turisztikai szakemberek tisztában legyenek az iparág ár- 
nyoldalaival is. Mind az alkalmazottak, mind az üzleti partnerek felvilágosítása elengedhetetlen.

Végiggondolt, megtervezett turisztikai fejlesztésekre van szükség, a desztináció helyi kultúrájának, szokásainak tiszteletben tartásával. DIMITRIOU (2017) megfogalmazása szerint a turizmustervezés egy olyan komplex folyamat, amely gazdasági, környezeti, kulturális és társadalmi faktorokat úgy vesz számításba, hogy a helyi lakosság is részt vesz az eljárásban. A fejlesztéseket vizsgálni kellene bû́nmegelőzési szempontból, illetve vizsgálni kellene azt is, milyen hatása lesz az egyes turisztikai fejlesztéseknek a helyiekre, különös tekintettel a védtelen, sérülékeny csoportokra, például a gyermekekre. Ugyanakkor a desztináció menedzsmentben is fontos szerephez kell, hogy jussanak a thelyiek, hiszen ezáltal tud olyan „interaktív térré alakulni a desztináció, ami mind a helyi lakosok, mind a turisták számára kölcsönös hasznot hordoz" (WEARING et al. 2012, idézi: ERNSZT 2016a:333).

A vendégszeretet kiemelkedően fontos tényező a turisták adott desztinációhoz való visszatérésében. A helyi lakosság kizsigerelése, a deviáns magatartások elszaporodása ellenérzéseket válthat ki a helyi lakosságból a turistákkal szemben. Ebben az esetben pedig vajmi kevés az esélye a helyiek vendégszeretetének.

\subsection{DEVIÁNS MAGATARTÁSOK, BÜNÖZÉS}

A biztonság megteremtése egy desztinációban legyen az a turistáké vagy a helyi lakosságé - elsősorban a hatóságok feladata, így minden lehetséges intézkedést meg kell tenniük annak garantálása érdekében. Alapvető jelentőségú, hogy az államok csatlakozzanak a vonatkozó nemzetközi szerződésekhez, és megfelelő belső jogi normákat hozzanak, amelyeket végre is hajtanak! A búncselekmények megelőzése, illetve felderítése során nemzetközi szinten múködjenek együtt más államokkal, nemzetközi szervezetekkel és a civil szférával is, különös tekintettel a turisztikai ipar érintettjeire. Mivel a deviáns magatartások kezelése csak holisztikus megközelítéssel lehetséges, azt is meg kell akadályozni, hogy a helyi lakosság egyes rétegei a társadalom perifériájára szoruljanak, és ezáltal könnyebben váljanak búncselekmények áldozataivá. Így minden olyan intézkedés, aminek ez a célja, hozzájárul a megelőzéshez: a biztonságos, óvó családi és társadalmi környezet, a védtelen, kiszolgáltatott csoportokat védô intézkedések bevezetése, oktatás biztosítása, de akár a munka-, megélhetési lehetôségek biztosítása is.

A turisztikai szektor alanyai szintén sokat tehetnek a turizmushoz kötődő búncselekmények megelőzése, illetve felderítése érdekében (3. táblá$z a t)$. Nagyon tágan kell meghatározni az érintettek körét ebben az esetben: a helyi lakosság, a turizmus területén múködő szolgáltatók, sőt maguk a turisták is ide sorolandók.

3. táblázat

Egyes turisztikai vállalkozások jó gyakorlatai a gyermekek szexuális kizsákmányolása elleni fellépés terén

\begin{tabular}{|c|c|}
\hline Vállalkozás & Alkalmazott gyakorlat \\
\hline Hyatt Hotels & $\begin{array}{l}\text { - a búncselekményt elitéló emberi jogi } \\
\text { nyilatkozat } \\
\text { - tréningek tartása a munkavállalók } \\
\text { számára } \\
\text { - gyermekekkel szembeni visszaélések } \\
\text { jelentésének támogatása (weblapot } \\
\text { múködtet e célra, ahol anonim módon } \\
\text { lehet jelenteni a gyanús eseteket, a } \\
\text { vezetôség számára személyesen is) } \\
\text { - emberkereskedelem céljára használt, } \\
\text { gyanús weboldalak blokkolása } \\
\text { - bünüldözó hatóságokkal való } \\
\text { együttmúködés } \\
\text { - veszélyeztetett fiatalok támogatása, } \\
\text { képzése, hogy munkát tudjanak vállalni }\end{array}$ \\
\hline TUI Csoport & $\begin{array}{l}\text { - gyermekek önvédelmi mechanizmusának } \\
\text { - megerősitése } \\
\text { - munkalehetôség teremtése fiatalok } \\
\text { - számára a helyi munkaerópiacon } \\
\text { - gyermekvédó szervezetek támogatása } \\
\text { turisztikai iparág szereplóinek } \\
\text { figyenyitése a téma tekintetében, } \\
\text { figelhívás a problémára }\end{array}$ \\
\hline
\end{tabular}

Forrás: saját szerkesztés HYATT HOTELS CORPORATION (2016) és TUIGROUP (2016) alapján

Sok esetben a turisztikai szolgáltatók által múködtetett helyszíneken követik el a búncselekményeket: hotelekben, apartmanházakban, bárokban. A turisztikai szektor alkalmazottjainak speciális tréningeken meg kell tanítani, melyek azok a jelek, amelyek ember- vagy gyermekkereskedelem, illetve szexuális visszaélések gyanújára adnak okot. Mindezt nem általánosságban, megközelítve, hanem rendkívül részletesen, alaposan, az egyes munkakörökben dolgozók számára lebontva kell megfogalmazni. Rutineljárásokat kellene kidolgozni arra vonatkozóan, hogy ilyen esetekben pontosan mit kell tenni, milyen beavatkozási lehetőségei vannak az alkalmazottnak.

Egy gyorstalpaló tréning azonban nem elegendő, a siker kulcsa az, hogy maga a felsô vezetés is támogassa ezt a fajta kultúrát. Ahogy azt egy hotel alkalmazottja fogalmazta meg: „Bármilyen, a témában tartott tréning hasznos, 
azonban csak a legfelsőbb szintú vezetés elkötelezettsége esetén tudunk csak hatékonyan fellépni." Az alkalmazottak azt javasolták, hogy olyan képzéseket tartsanak számukra, amelyeknek a „kultúra kialakítása a célja”. Egy másik alkalmazott szavai ugyanezt erősítették meg, ő kifejtette, hogy „a felettese soha nem tenne semmit a jelentése alapján, és nem kockáztatná, hogy jelentse a gyanús esetet" (PARASKEVAS - BROOKES 2018:153).

Ha a turisták nyitott szemmel járnak, maguk is tapasztalhatják és láthatják, hogy sokszor a szemük láttára követnek el bizonyos búncselekményeket, vagy éppen nekik ajánlanak fel különféle illegális „szolgáltatásokat”. Ezért fontos valamennyi érintett tájékoztatása, és arra való ösztönzése, hogy jelentsék a rendőrségnek a gyanús eseteket. Emellett az sem elhanyagolható jelentőségú, ha kampányok segítségével magukat a turistákat, azaz sok esetben a potenciális búnelkövetőket, szembesítik a búntettek következményeivel.

A szexuális kizsákmányolás, gyermekmunka vagy emberkereskedelem búntettének megvalósulása esetén elengedhetetlen (lenne) az elkövetôk súlyos megbüntetése. A(z) (gyermek)áldozatokat nem búnözôként, hanem áldozatként kell kezelni, és segítségükkel kíméletesen, további pszichés sérülések előidézése nélkül, a lehetô legtöbb információhoz jutni (NEWMAN et. al. 2011). Pszichológiai támogatásuk elengedhetetlen, hiszen súlyos traumákat szenvedtek el, de ugyanilyen fontos a társadalomba való integrációjuk is (PARLIAMENTARY ASSEMBLY 2013, HAWKE - RAPHAEL 2016, PETRA DEVELOPMENT AND TOURISM REGION AUTHORITY et al. 2014).

A fénnyel mindig együtt jár az árnyék, még egy olyan iparágban is, ami a legtöbbek számára boldogságot, pihenést, megélhetést jelent. Hiszen vannak olyanok is, akiknek a turizmus a mindennapjait lehetetleníti el azzal, hogy emberi méltóságuktól fosztva meg őket mérhetetlen szenvedést, kiszolgáltatottságot okoz számukra. Nyíltan, szégyenkezés nélkül kell beszélni a turizmus ezen kevésbé tetszetôs, másik oldaláról is, hogy mindenki ki tudja venni a részét az ellene való harcból, és a nyári élmények „árát” ne az ártatlan áldozatok vagy a helyi lakosság fizesse meg.

\section{Köszönetnyilvánítás}

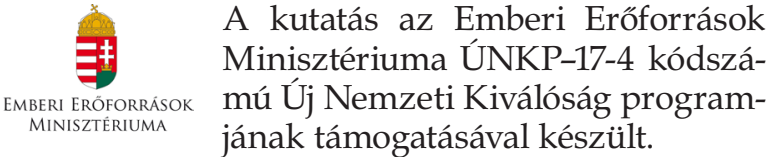

\section{Felhasznált irodalom}

BADARIAH, H. D. - HABIBULLAH, M. S. BAHAROM, A. H. - SAARI, M. D. (2016): Are Shadow Economy and Tourism Related? International Evidence. Procedia Economics and Finance. 35. pp. 173-178.

BANDYOPADHYAY, R. (2012): A paradigm shift in sex tourism research. Tourism Management Perspectives. 6. pp. 1-2.

BAUER, I. (2014): Romance tourism or female sex tourism? Travel Medicine and Infectious Disease. 12. pp. 20-28.

BERDYCHEVSKY, L. - GIBSON, H. - PORIA, Y. (2013): Women's Sexual Behavior In Tourism: Loosening The Bridle. Annals of Tourism Research. 42. pp. 65-85.

BIAGI, B - BRANDANO, M. G. - DETOTTO, C. (2012): The Effect of Tourism on Crime in Italy: A Dynamic Panel Approach. Economics. The Open-Access, Open-Assessment E-Journal. 6(2012-25). pp. 1-24. http://dx.doi.org/10.5018/ economics-ejournal.ja.2012-25, Letöltve: 2018. március 7.

CHEMIN, M. - MBIEKOP, F. (2015): Addressing Child Sex Tourism, The Indian Case. European Journal of Political Economy. 38. pp. 169-180.

DAHLES, H. - BRAS, K. (1999): Entreprenours in Romance Tourism in Indonesia. Annals of Tourism Research. 26(2). pp. 267-293.

DIMITRIOU, C. K. (2017): The quest for a practical approach to morality and the tourism industry. Journal of Hospitality and Tourism Management. 31. pp. $45-51$.

ERNSZT I. (2016a): Kőszeg slow turizmusban rejlő lehetôségei - A lassú filozófia. In: Miszlivetz F. (szerk.): Kisvárosok reneszánsza, A kôszegi példa. Savaria University Press - Felsőbbfokú Tanulmányok Intézete, Szombathely - Kőszeg.

ERNSZT, I. (2016b): „Sullen Shadows under the Blue Sky"- Some Remarks about the Dark Side of Tourism and the International Legal Protection. In: Németh K. (szerk): I. Turizmus és Biztonság Nemzetközi Tudományos Konferencia. Pannon Egyetem Nagykanizsai Kampusz. Konferenciakötet. pp. 98-106.

ERNSZT, I (2018): Children from the Unhappy Side of Tourism. Proceedings of the MakeLearn and TIIM International Conference. Naples, Italy.

HAWKE, A. - RAPHAEL, A. (2016): Offenders on the Move. Global Study On Sexual Exploitation Of Children In Travel And Tourism 2016. ECPAT. http://www.globalstudysectt.org/wp-content/ uploads/2016/05/Global-Report-Offenderson-the-Move-Final.pdf, Letöltve: 2017. szeptember 25 . 
HUA, N. - YANG, Y. (2017): Systematic effects of crime on hotel operating performance. Tourism Management. 60. pp. 257-269.

HYATT HOTELS CORPORATION (2016): Annual Report, 2016. http://www.thecode.org/whohave-signed/top-members/, Letöltve: 2017. november 27.

ILO (INTERNATIONAL LABOUR OFFICE) (2009): Training Manual to Fight Trafficking in Children for Labour, Sexual and Other Forms of Exploitation. Understanding Child Trafficking. Textbook 1. https://www.unicef.org/ protection/Textbook_1.pdf, Letöltve: 2017. október 26.

INTERPOL (2018): Crimes Against Children. https://www.interpol.int/Crime-areas/ Crimes-against-children/Crimes-againstchildren, Letöltve: 2018. március 16.

LENGYEL M. (1997): A turizmus versenyképességét befolyásoló tényezôk. Múhelytanulmányok. 16. kötet. Budapesti Közgazdaságtudományi Egyetem, Budapest.

MAGYARORSZÁG ÜGYÉSZSÉGE

(2018): Lányokat futtatott külföldön a zalai búnbanda. http://ugyeszseg.hu/lanyokat-futtatottkulfoldon-a-zalai-bunbanda/, Letöltve: 2018. február 27.

NEWMAN, W. J. - HOLT, B. W. - RABUN, J. S. - PHILliPS, G. - SCOTT, C. L. (2011): Child sex tourism: Extending the borders of sexual offender legislation. International Journal of Law and Psychiatry. 34(2). pp. 116-121.

O'BRIAIN, M. - GRILLO, M. - BARBOSA, H. (2008): End Child Prostitution, Child Pornography and Trafficking of Children for Sexual Purposes. Sexual exploitation of children and adolescents in tourism. A Contribution of ECPAT International to the World Congress III against Sexual Exploitation of Children and Adolescents. Rio de Janeiro, Brazil. http://www.ecpat. org/wp-content/uploads/legacy/Thematic Paper_CST_ENG.pdf, Letöltve: 2018. január 17.

OMONDI, R. K. - RYAN, C. (2017): Sex tourism: Romantic safaris, prayers and witchcraft at the Kenyan coast. Tourism Management. 58. pp. 217-227.

PARASKEVAS, A. - BROOKES, M. (2018): Nodes, Guardians and Signs: Raising Barriers to Human Trafficking in the Tourism Industry. Tourism Management. 67. pp. 147-156.

PARLIAMENTARY ASSEMBLY, COUNCIL OF EUROPE, (2013): Fighting "child sex tourism”, Resolution 1926 (2013) http://assembly.coe. int/nw/xml/XRef/Xref-XML2HTML-en. asp?fileid=19687\&lang=en, Letöltve: 2017. december 17.

PÉTER, E. - KELLER, K. - NÉMETH, K. LELKÓNÉ TOLLÁR, I. (2017): Integrating health literacy into work and relaxation. In: Kiglics N. (szerk): II. Turizmus és Biztonság Nemzetközi Tudományos Konferencia. Pannon Egyetem Nagykanizsai Kampusz. Tanulmánykötet. pp. 392-397.

PETRA DEVELOPMENT AND TOURISM REGION AUTHORITY - ILO - UNICEF - USAID (2014): Plan of Action to Eliminate Child Labour in Tourism in Petra. http:// www.ilo.org/ipecinfo/product/download. do?type=document\&id=26595, Letöltve: 2018 . február 27.

Report of the 30th meeting of the World Tourism Network on Child Protection (2015), ITB Berlin, Germany. http://dtxtq4w60xqpw. cloudfront.net/sites/all/files/docpdf/ rev30thmeetingreportof theworldtourism networkonchildprotectionrevnm.pdf, Letöltve: 2016. március 30.

SCHNEIDER, F. - A. T. KEARNEY - VISA EUROPE (2013): The Shadow Economy in Europe. https://www.atkearney.com/financialservices/article?/a/the-shadow-economy-ineurope-2013, Letöltve: 2018. március 7.

SHARMA, A. - KUKREJA, S. - SHARMA, A. (2012): Child labour - An Ugly Face of Travel and Hospitality Industry. IOSR Journal of Business and Management. 4(1). pp. 08-17.

SPENCER, A. - BEAN, D. (2017): Female sex tourism in Jamaica: An assessment of perceptions. Journal of Destination Marketing and Management. 6. pp. 13-21.

THE CODE: http://www.thecode.org/about/

TUIGROUP (2016): A Collective No to sexual exploitation of children in holiday destinations. http://cf.cdn.unwto.org/sites/all/files/ pdf/160307_unwto_network_on_child_ protection_tui_group.pdf, Letöltve: 2017. december 10 .

UN GA (UNITED NATIONS GENERAL ASSEMBLY) (2006): Promotion and protection of the rights of children. UN General Assembly Resolution. A/61/299. http:// www.un.org/en/ga/search/view_doc. asp?symbol=A/61/299\&Lang=E, Letöltve: 2018. március 16.

UNICEF (2011): Child Protection from Violence, Exploitation and Abuse. https://www.unicef. org/protection/, Letöltve: 2018. március 9)

UNWTO (2014): 15 Years of the UNWTO World Tourism Network on Child Protection: A Compilation of Good Practices. https://www.e- 
unwto.org/doi/pdf/10.18111/9789284415588, Letöltve: 2016. február 25.

WEARING, S. L. - WEARING, M. - McDONALD, M. G. (2012): Slow'n Down the Town to Let Nature Grow: Ecotourism, Social Justice and Sustainability. In: Fullagar, S. - Markwell, K. - Wilson, E. (eds): Slow Tourism: Experiences and Mobilities. Channel View Publications. pp. 36-50.

WEICHSELBAUER, D. (2012): Sex, romance and the carnivalesque between female tourists and Caribbean men. Tourism Management. 33(5). pp. 1220-1229.
WOLF, Y. (1993): The World of the Kuta Cowboy. A Growing Subculture of Sex, Drugs and Alcohol is Evident Among Male Youth in the Tourist Areas of Bali and Lombok as they Seek an Alternative to Poverty. Inside Indonesia. June. pp. 15-17.

YEOMAN, I. - MARS, M. (2012): Robots, men and sex tourism. Futures. 44. pp. 365-371.

ZSARNOCZKY, M. (2016): The impact of silver tourism on rural areas. Annals of The Polish Association of Agricultural and Agribusiness Economists. 18(3). pp. 402-410. 